\title{
Crustal structure and evolution of the Mawson Sea, western Wilkes Land margin, East Antarctica
}

\author{
G. L. Leitchenkov, ${ }^{1}$ V. V Gandyukhin, ${ }^{2}$ Yu. B. Guseva, ${ }^{2}$ and A. Yu. Kazankov ${ }^{2}$ \\ ${ }^{1}$ Institute for Geology and Mineral Resources of the World Ocean, 1, Angliysky Ave. 190121, St.-Petersburg, Russia (german_1@mail.ru) \\ ${ }^{2}$ Polar Marine Geosurvey Expedition, 24, Pobedy St., 189510, Lomonosov, St.-Petersburg, Russia (antarctida@peterlink.ru)
}

\begin{abstract}
This study is based on about $4000 \mathrm{~km}$ of MCS, magnetic and gravity data as well as 10 sonobuoys collected by the 2005 Russian Antarctic Expedition in the Mawson Sea and adjacent Australian-Antarctic basin between $102^{\circ} \mathrm{E}$ and $115^{\circ} \mathrm{E}$. Major identified tectonic provinces and features of the study region include: 1) A marginal rift about $300 \mathrm{~km}$ wide which developed as a result of extreme crustal extension and unroofing of the upper mantle, and 2) An oceanic basin with the crust of not older than $81 \mathrm{Ma}$, which is characterized by ultraslow sea-floor spreading rates ranging from 3 to $11 \mathrm{~mm} / \mathrm{yr}$. Three major unconformities are identified in the sedimentary cover of the Mawson Sea and are interpreted to be caused by break-up between Australia and Antarctica at about $81 \mathrm{Ma}$ ago (WL1), the first arrival of the ice sheet to the Mawson Sea (WL3) and continental scale glaciation at about 34 Ma ago (WL4).

Citation: Leitchenkov, G.L., V.V. Gandyukhin, and Y.B. Guseva (2007), Crustal structure and evolution of the Mawson Sea, western Wilkes Land margin, East Antarctica, in Antarctica: A Keystone in a Changing World - Online Proceedings of the 10th ISAES, edited by A. K. Cooper and C. R. Raymond et al., USGS Open-File Report 2007-1047, Short Research Paper 028, 4 p.; doi:10.3133/of2007-1047.srp028.
\end{abstract}

\section{Introduction}

The Mawson Sea (MS) is located on the western Wilkes Land margin (East Antarctica) and joins the Australian-Antarctic Basin (AAB) in the north. About $4100 \mathrm{~km}$ of multichannel seismic (MCS), gravity and magnetic (gradientometric) data as well as 10 sonobuoys were acquired in the MS (between $102^{\circ} \mathrm{E}$ and $115^{\circ} \mathrm{E}$ ) during 2005 cruise of RV "Akademik A. Karpinsky" (the Russian Antarctic Expedition, RAE; Fig. 1). MCS data were recorded using a 352-channel, $4400 \mathrm{~m}$ long digital streamer and airgun array of 2860 cub. in. in total volume. Earlier, the MS had been studied by Japanese (1994/1995 season; Ishihara et al., 1996) and Australian (2000-2001 seasons; Colwell et al., 2006) expeditions which collected about $5000 \mathrm{~km}$ of MCS and potential field data (Fig. 1).

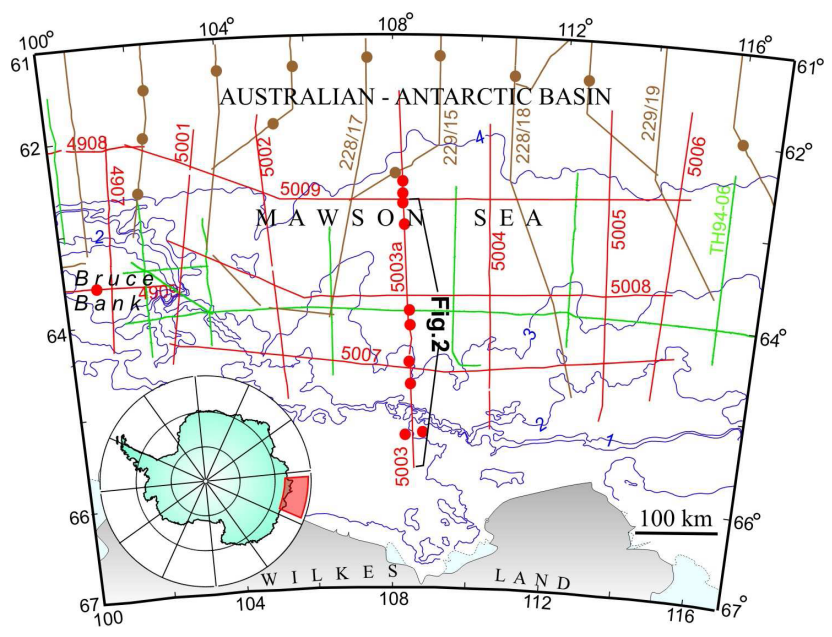

Figure 1. Geophysical studies in the Mawson Sea. Profiles (lines) and sonobuoys (circles) are colored in accordance with national contributions: red color stands for Russian, gray - for Australian and green - for Japanese cruises.
This paper is based on the interpretation of geophysical data from the MS and focuses on crustal structure and evolution of this part of the Antarctic passive margin.

\section{Crustal structure and seismic stratigraphy}

Major crustal and tectonic provinces of the MS are mainly interpreted from the morphology and seismic pattern of the acoustic basement (AB). Ice conditions and strong multiples precluded identification of the $A B$ surface beneath the continental shelf and slope but oceanward it is recognized as the lowermost relief boundary, marked locally by hyperbolic reflections (diffractions) below the stratified sedimentary cover (Fig. 2). The $A B$ of the MS and the $A A B$ is subdivided into four types (numbered from I to IV) each having different geophysical and structural characteristics (Fig. 3).

Under the inner shelf, the $\mathrm{AB}$ is proposed to occur at shallow level but under the outer shelf, it is submerged to about $10 \mathrm{~km}$. Beneath the most of the upper and middle continental rise, the $\mathrm{AB}$ (referred to as Type I) lies at a depth of between 8 and $10 \mathrm{~km}$ and has a generally subhorizontal distorted (faulted) surface with a relief of 0.3-0.5 km (Fig. 2 and 3). Two pairs of reversed sonobuoy measurements show basement velocity 6.0 $\mathrm{km} / \mathrm{s}$ (Fig. 3). AB Type II is located oceanward of Type I and is about $65-100 \mathrm{~km}$ in width (Fig. 3). Its averaged surface ascends gently toward the north occurring at a depth of between 7.5 and $9.5 \mathrm{~km}$ and is distinguished by numerous diffractions (on unmigrated seismic lines) that mark its upper boundary and that are also observed downwards. In places, below the AB surface, discontinuous reflectors can be recognized. Also, a specific feature here is the $\mathrm{AB}$ highs (ridges?) that are about $25 \mathrm{~km}$ wide. The most prominent of these highs was crossed by line 5003 and has an amplitude of $4 \mathrm{~km}$ (Fig. 2 and 3). Basement velocity modeled by one pair of 

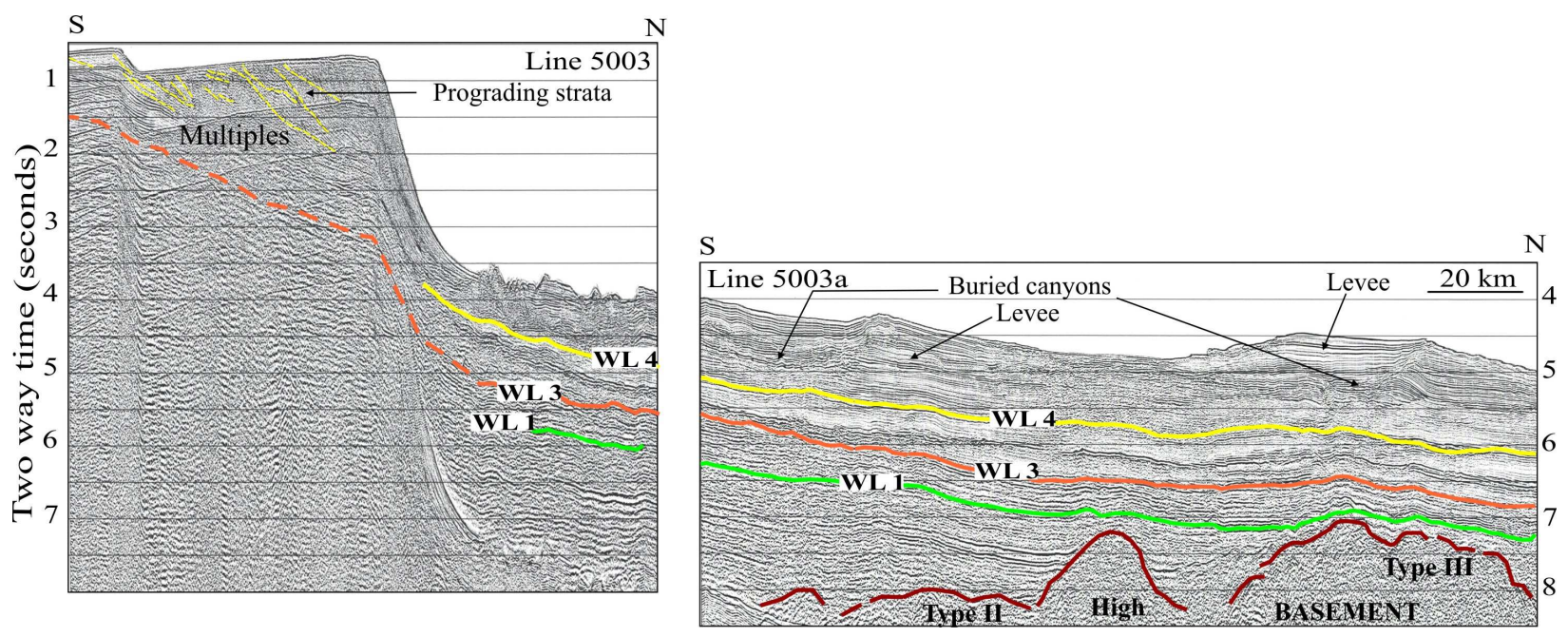

Figure 2. Interpreted seismic section showing acoustic basement structure (basement types II and III) and seismic stratigraphy of the Mawson Sea. See Fig. 1 for line location.

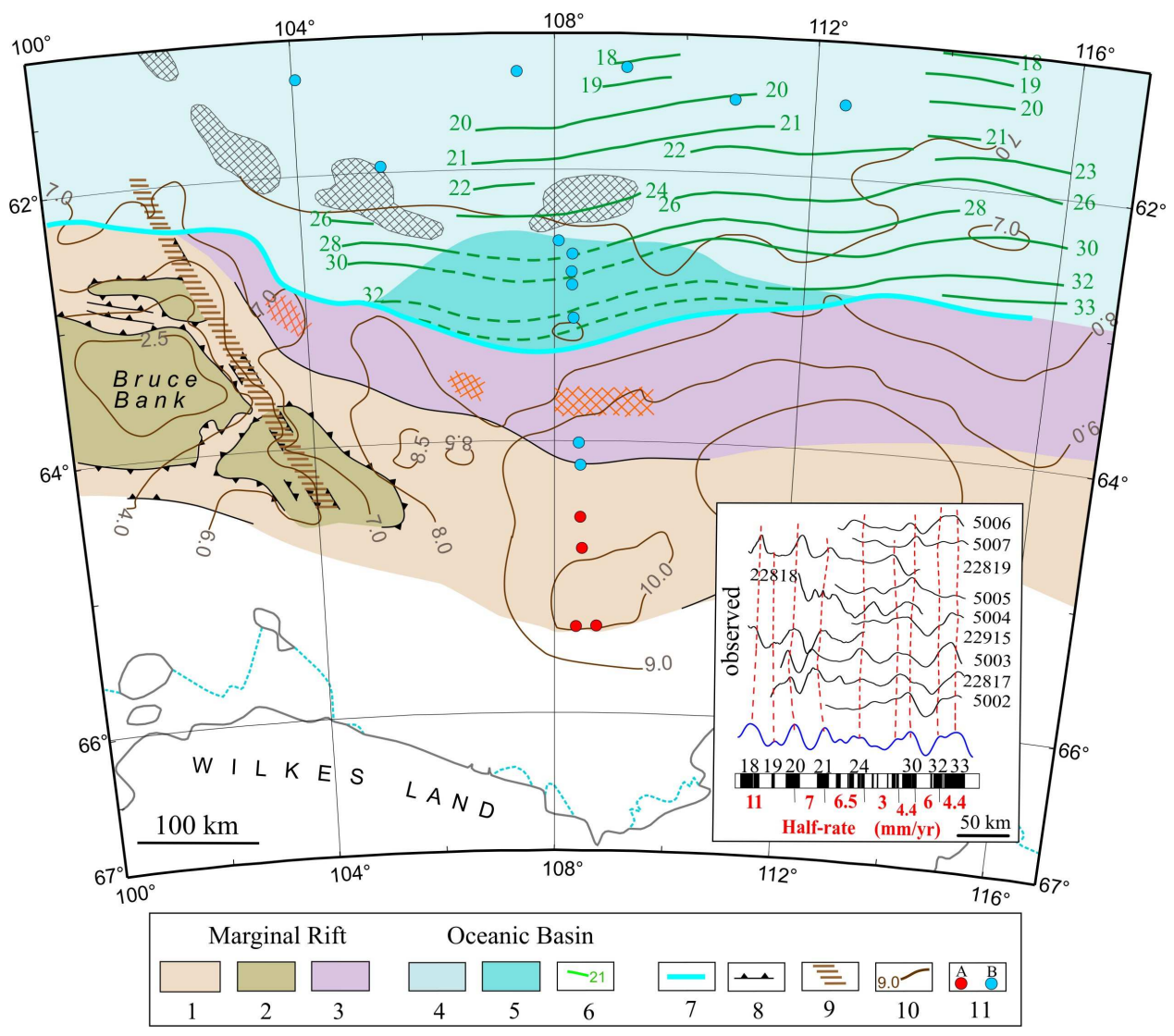

Figure 3. Acoustic basement $(\mathrm{AB})$ types, tectonic provinces and structural features of the Mawson Sea and the Australian-Antarctic Basin. 1 - AB Type I (stretched continental crust); 2 - basement uplifts of the Bruce Bank (marginal volcanic plateau); 3 - AB Type II (heavily altered syn-rift sediments underlain by ultramafic crust); hatched areas are gabbro/peridotite highs (exhumed mantle); 4 - AB Type III (oceanic crust with possibly abnormal sea-floor spreading); 5 - AB Type IV (normal oceanic crust); hatched areas are gabbro/peridotite highs (amagmatic paleoridge segments); 6 - magnetic lineations with numbers of polarity chrons; 7 - continent-to-ocean boundary; 8 - escarpments and/or normal faults; 9 - Vincennes Fracture Zone; 10 - depths to basement (in km); 11 - refraction velocities at the AB surface (A - 5.8-6.0 km/s; B - 4.9-5.2 km/s). See text for explanations. Inset: Synthetic sea floor spreading model for the Australian-Antarctic Basin (see Fig. 1 for location of magnetic lines). 
sonobuoys averages $5.0 \mathrm{~km} / \mathrm{s}$ (Fig. 3). AB Types I and II are characterized by low amplitude (50-150 nT), sublinear (parallel to the margin) magnetic anomalies. In the west, the deeply submerged AB of Types I and II is bordered by basement uplifts of the Bruce Bank described elsewhere (Stagg et al., in press; Guseva et al., this volume) and is dissected by a linear NW-SE-trending depression referred to as Vincennes Fracture zone (Tikku and Cande, 1999).

AB Type III is locally mapped by a few lines between $105^{\circ} \mathrm{E}$ and $112^{\circ} \mathrm{E}$, being about $100 \mathrm{~km}$ wide in the central part (along longitude $108^{\circ} \mathrm{E}$; Fig. 3). It shows a moderately rough surface lying at a depth of 7.0-7.5 km and has characteristics similar to those of Type II (including velocities of $5.0 \mathrm{~km} / \mathrm{s}$ ), although its internal structure is less clear here. AB Type IV is developed within the $\mathrm{AAB}$ and is characterized by a highly rugged surface with a relief of 1.5-2.0 km (Fig. 3). Its averaged surface level progressively ascends oceanward from about $7.5 \mathrm{~km}$ to $6.5-6.0 \mathrm{~km}$. Among the poorly ordered, irregular basement morphology, the chain of isolated oblong basement highs of $25-50 \mathrm{~km}$ wide is well mapped by satellite derived gravity anomalies of $30-40 \mathrm{mGl}$ amplitude (Sandwell and Smith, 1997) to the west of $109^{\circ} \mathrm{E}$ (Fig. 3). AB Types III and IV show distinct E-W trending variable-polarity magnetic lineations. The full thickness of the MS and the AAB crust, determined from seismic refraction data and gravity modeling, is about 23$15 \mathrm{~km}$ under the shelf, $12-13 \mathrm{~km}$ under the continental rise and 8-10 km under the abyssal plain.

Three major unconformities labeled WL1, WL3 and WL4 are identified in the MS sedimentary cover (Fig. 2) based on a unified seismic stratigraphy model constructed for the larger part of the East Antarctic margin (Leitchenkov et al., this volume). In this unified model, unconformities are numbered up-section from " 1 " to " 5 " and lettered to denote their different geographic locations and tectonic setting (note that unconformity " 2 " is missing in the MS). Unconformity WL1 has limited development onlapping the $\mathrm{AB}$ landward of (in the eastern MS) or very close to (in the western MS) the boundary between AB Type II and Types III or IV. The unit below WL1 is characterized by clear stratification with few internal continuous reflectors and has the thickness of more than $3 \mathrm{~km}$. Unconformity WL3 marks a remarkable change in seismic patterns from parallelbedded below to more complex above. Strata overlying WL3 are characterized by a variety of seismic facies which include a semitransparent layer (Fig. 2) forming a giant lobe in the eastern MS, small mounds with chaotic reflectors and buried channel-levee systems. WL3 corresponds with unconformity "eoc" identified by Colwell et al. (2006) over the entire Wilkes Land margin and with unconformity WL-U3 identified by DeSantis et al (2003) in the eastern Wilkes Land margin. Unconformity WL4 heralds a broader growth of channelslevees and development of mud waves fields.

\section{Discussion}

The MS formed as a part of the Wilkes Land nonvolcanic margin and the southern $\mathrm{AAB}$ during the longterm (over c. $70 \mathrm{Ma}$ ) Middle Jurassic to Late Cretaceous rifting and subsequent break-up between Australia and Antarctica in the Late Cretaceous - Paleocene (Tikku and Cande, 1999). Tikku and Cande (1999) argued that early sea-floor spreading in the ABB occurred in an ultra-slow regime (with half-rates between 1.5 and $6.5 \mathrm{~mm} / \mathrm{y}$ ) from anomaly 34 to anomaly 18 , noting that magnetic anomalies older than 31 are possibly not isochrons and in places sea-floor spreading could be compensated by crustal extension.

The $\mathrm{AB}$ types identified in the MS and the $\mathrm{AAB}$ are thought to correspond with major crustal and tectonic provinces (Fig. 3). We interpret AB Type I with a velocity of $6.0 \mathrm{~km} / \mathrm{s}$ (typical for upper continental crust) as stretched and deeply submerged complexes of the East Antarctic Precambrian Shield (Fig. 3).

Among other AB types, Type IV seems to be most definitive in nature. Its rugged relief, regular northward shallowing, featureless internal reflection pattern and clear magnetic lineation allow us to interpret it as unequivocal oceanic crust. A high-amplitude relief of basement surface is typical for ultraslow sea-floor spreading regime. The chain of oblong basement highs in this crust to the west of $109^{\circ} \mathrm{E}$ is interpreted to be peridotite (partly serpentinized) highs representing amagmatic accretionary paleoridge segments which are common features of slowly divergent plates (Dick et al., 2003).

The crust presented by AB Type II (showing a complex internal structure, velocity values of about 5.0 $\mathrm{km} / \mathrm{s}$, non-regular magnetic field and high-amplitude basement highs) exhibits neither typical oceanic nor continental geophysical characteristics. Following Sayers et al. (2001) who mapped the same AB type on the conjugate Australian margin and Colwell et al. (2006) who specify this $\mathrm{AB}$ type on the Antarctic margin (continent-ocean transition in their interpretations), we interpret $\mathrm{AB}$ Type II as an intensively deformed and altered syn-rift sedimentary unit abundantly intruded by igneous rocks. However, unlike our Australian colleagues who propose that the syn-rift unit is underlain by the lower crust, we infer that it is underlain by ultramafic crust (serpentinised mantle rocks). The top of this crust is recognized in places as the lower visible reflector at the base of a complexly-structured AB Type II (especially on better MCS images derived in 2007 to the east of the MS). In this context, contrasting basement highs within AB Type II are interpreted to be peridotite or gabbro buildups (Fig. 3). The nature of crust containing AB Type III is vague but a clear magnetic lineation in this area persuades us to interpret it as oceanic crust with possibly abnormal (intermittent and unstable) sea-floor spreading.

Thus we infer that the outer continental margin developed as a result of extreme crustal extension and 
syn-tectonic mantle unroofing in the uppermost level of the lithosphere (culminating in the formation of gabbro and peridotite highs/ridges) similar to the model suggested for Iberia margin (Boillot and Froitzheim, 2001). The continent-ocean boundary (COB) is interpreted to be located along the oceanward limit of $\mathrm{AB}$ Type II, and in that case the width of extended continental crust amounts to $300 \mathrm{~km}$ (Fig. 3).

Integration of all available magnetic data enables us to correlate and identify oceanic magnetic anomalies (Fig. 3, Inset). Our spreading rate model is generally consistent with that suggested by Tikku and Cande (1999) however their anomaly 34 is now situated within the extended (ultramafic) crust and is thought to be caused by intraplate intrusive emplacement. The oceanic crust of the study region is characterized by sea-floor spreading lineations from 33 to 18 with a spreading half-rate ranging between 3 and $11 \mathrm{~mm} / \mathrm{yr}$ (Fig. 3, Inset). Revised identification suggests that break-up between Australia and Antarctica commenced within anomaly 33 , i.e. at about $79-81 \mathrm{Ma}$ ago.

Interpretation of seismic stratigraphy is based on correlation of unconformities with major events associated with regional tectonic evolution. The lower unconformity WL1 is interpreted to correlate with continental break-up. Unconformity WL3 onlaps the early Eocene oceanic crust between magnetic anomalies 22-24 and so is not older than this age. Seismic patterns identified above this unconformity are typical for downslope processes in contrast to underlying parallelbedded strata inherent to hemipelagic sedimentation. We propose that the marked changes across WL3 are associated with the first arrival of the ice sheet to this part of the Antarctic margin and the triggering of gravitydriven sedimentation events. WL4 heralds more abundant development of channel-levee systems in the MS and corresponds with the onset of continental scale Antarctic glaciation at the Eocene/Oligocene boundary (Leitchenkov et al., this volume).

\section{Summary}

The MS is a non-volcanic passive margin developed as a result of extreme crustal extension and syn-tectonic unroofing of the upper mantle to form the marginal rift of up to $300 \mathrm{~km}$ wide. Sea-floor spreading following crustal extension commenced at about 79-81 Ma ago. Oceanic crust of the study region is characterized by sea-floor spreading lineations from 33 to 18 with half-rate ranging between 3 and $11 \mathrm{~mm} / \mathrm{yr}$. Three major unconformities labeled WL1, WL3 and WL4 are identified in the MS sedimentary cover. Unconformity WL1 is interpreted to correspond with continental break-up; WL3 is associated with the first arrival of the ice sheet to this part of the Antarctic margin; and WL4 corresponds with the onset of continental scale Antarctic glaciation at the Eocene/Oligocene boundary.

Acknowledgments. We are grateful to anonymous reviewer and John Gamble for comments which improved this paper. Funding for this work was partly provided by Federal Target Program "World Ocean" (Subprogram "Antarctica", Project 13).

\section{References}

Boillot, G., and N. Froitzheim (2001), Non-volcanic rifted margins, continental break-up and onset of seafloor spreading: some outstanding questions, Non-Volcanic rifting of continental margins: a composition of evidence from land and sea, edited by R.C.L. Wilson, R.B. Whitmarsh, B. Taylor, and N. Froitzheim, London, Special Publication, 187, 9-30.

Colwell, J.B., H.M.J Stagg, N.G. Direen, G. Bernardel, and I. Borissova (2006), The structure of the continental margin off Wilkes Land and Terre Adelie Coast, East Antarctica. Antarctica. Contributions to Global Earth Sciences, Proc. IX Int. Symp. of Antarctic Earth Sci., edited by Futterer, D. K., D. Damaske, G. Kleinschmidt, H. Miller, and F. Tessensohn, 327-340, Springer.

DeSantis, L., G. Brancolini, and F. Donda (2003), Seismo-stratigraphic analysis of the Wilkes Land continental margin (East Antarctica): influence of glacially-driven processes on the Cenozoic deposition. Deep-Sea Research II, 50, 8-9, 1563-1594.

Dick, H.J.B., J. Lin, and H. Schouten (2003), An ultraslow-spreading class of ocean ridge, Nature, 426, 27, 405-412.

Guseva, Yu.B., G.L. Leitchenkov, V.V. Gandyukhin, and S.V. Ivanov (2007), Basement and crustal structure of the Davis Sea region (East Antarctica): implications for tectonic setting and continent to ocean boundary definition, this volume.

Ishihara, T., M. Tanahashi, M. Sato, and Y. Okuda (1996), Preliminary report of geophysical and geological surveys of the west Wilkes Land margin, Proceedings of the NIPR Symposium on Antarctic Geoscience, 9, 91-108.

Leitchenkov, G.L., Yu.B. Guseva, and V.V. Gandyukhin (2007), Cenozoic environmental changes along the East Antarctic continental margin inferred from regional seismic stratigraphy, this volume.

Sandwell, D.T., and W.H.F. Smith (1997), Marine gravity anomaly from Geosat and ERS-1 satellite altimetry, J. Geoph. Res., 102, 1003910054.

Sayers, J., P. Symonds, N.G. Direen, and G. Bernardel (2001), Nature of the continent-ocean transition on the non-volcanic rifted margin of the central Great Australian Bight. Non-Volcanic Rifting of Continental Margins: A Comparison of Evidence from Land and Sea, edited by Wilson, R.C.L., R.B., Whitmarsh, B. Taylor, and N. Froitzheim, Geol. Soc., London, Spec. Publ., 187, 51-77.

Stagg, H.M.J., J.B. Colwell, I. Borissova, T. Ishihara, and G. Bernardel (2007), The Bruce Rise area, East Antarctica: formation of a continental margin near the Greater India - Australia - Antarctica triple junction, Terra Antarctica, in press.

Tikku, A.A., and S.C. Cande (1999), The oldest magnetic anomalies in the Australian-Antarctic Basin: are they isochrons?, J. Geoph. Res., 104, 661-677. 